Citation: Micael Santos, Xosé Antón Rodríguez, Ana Marta-Costa (2021) Productive efficiency of wine grape producers in the North of Portugal. Wine Economics and Policy 10(2): 3-14. doi: 10.36253/wep-8977

Copyright: (c) 2021 Micael Santos, Xosé Antón Rodríguez, Ana Marta-Costa. This is an open access, peer-reviewed article published by Firenze University Press (http://www.fupress.com/wep) and distributed under the terms of the Creative Commons Attribution License, which permits unrestricted use, distribution, and reproduction in any medium, provided the original author and source are credited.

Data Availability Statement: All relevant data are within the paper and its Supporting Information files.

Competing Interests: The Author(s) declare(s) no conflict of interest.

\section{Productive efficiency of wine grape producers in the North of Portugal}

\author{
Micael Santos ${ }^{1, *}$, Xosé Antón Rodríguez ${ }^{2}$, Ana Marta-Costa ${ }^{3}$ \\ ${ }^{1}$ Centre for Transdisciplinary Development Studies (CETRAD); University of Trás-os- \\ Montes e Alto Douro (UTAD), Quinta de Prados, Pólo II - ECHS, 5000-801 Vila Real, \\ Portugal,E-mail: micaels@utad.pt \\ ${ }^{2}$ Department of Quantitative Economics, University of Santiago de Compostela (USC), \\ Avda Xoán XXII, s/n, Santiago de Compostela, Spain, Email: xoseanton.rodriguez@usc.es \\ ${ }^{3}$ Centre for Transdisciplinary Development Studies (CETRAD); University of Trás-os- \\ Montes e Alto Douro (UTAD), Quinta de Prados, Pólo II - ECHS, 5000-801 Vila Real, \\ Portugal,Email: amarta@utad.pt \\ ${ }^{*}$ Correspond author.
}

\begin{abstract}
Portugal is a country traditionally dedicated to viticulture and characterized by the production of wines of high quality. It has been among the top of 15 countries in the sector in terms of vineyard area extension and wine production, however in recent years Portugal have lost market share in these fields. This situation can be related to the level of productive efficiency of vineyards. Therefore, this study aims to analyse the productive efficiency of wine-growing farms and the determinants that make farms more efficient. The specific hypothesis to be tested is if structural factors of the wine grape farms are determinant of its productive efficiency. To achieve this purpose, we use a database collected by face-to-face surveys from a sample of 154 wine-growing farms with specific input-output information from 2017. These farms are locating in the three regions of the North of Portugal (Minho, Douro and Trás-osMontes), which represents more than $40 \%$ of the Portuguese vineyard area. To analyse the productive efficiency of the farms, we use the Stochastic Frontier Analysis (SFA). The results show that the efficiency level in the wine-growing farms from the North of Portugal is around $68 / 67 \%$, but with significant differences at regional level. Many of these discrepancies may be due to structural factors, such as the type of wine grapes and the specific characteristics of the region. In conclusion, farms must adjust production management to the existing structural characteristics.
\end{abstract}

Keywords: technical efficiency, productivity, grape production, stochastic frontier analysis.

\section{INTRODUCTION}

The wine market is becoming increasingly competitive and is no longer an exclusive sector of the Southern European countries (Fleming et al., 2014; Goncharuk and Figurek, 2017). Literature designates the traditionally wine-producing countries as "Old World" and as "New World" the countries 
that were colonized by the former group, but the first continue to lead the 2018 market in the following order Italy, France and Spain (OIV, 2019). Portugal, being the $9^{\text {th }}$ with the largest vineyard area and the $11^{\text {th }}$ largest wine producer on a worldwide level, needs to improve its competitiveness position to get a better podium place in the world market and this can upstream of the sector. Viticulture is an expensive activity in the wine production (Moreira et al., 2011) and therefore it could play an important role to improve the sector competitiveness through its grapes production efficiency.

The North of the Portugal has three wine regions Minho, Douro and Trás-os-Montes - that integrates $42 \%$ of the total vine area of the country and corresponds to $35 \%$ of the national production of wine in 2019 (IVV, 2019).

Minho is located in the Northwest of Portugal and integrates Vinho Verde region (Green Wine, 23.999 ha, $12,5 \%$ and $759.757 \mathrm{hl}, 12,5 \%$ of total national) cradle of the famous Alvarinho variety; in the extreme northeast of the country to the north of the Douro region, there is the wine production region of Trás-os-Montes (TOM, $12.252 \mathrm{ha}, 6,4 \%$ and $50.670 \mathrm{hl}, 0,8 \%$ of total national); and the Demarcated Region of Douro (DRD, 43.863 ha, $22,8 \%$ and $1.259 .683 \mathrm{hl}, 20,8 \%$ of total national) is considered to be the first demarcated region of the world since 1756 (IVV, 2019). Douro is a mountain vineyard region with high slopes, which increases production costs due to the difficulty of mechanization and to the labour intensive activity. Nevertheless, it is a wine region characterized by the production of Port wine, a generous wine known internationally, where the grapes are sold at higher price.

Despite the geographical proximity of the three regions, they have very distinct characteristics in terms of climate, soil and types of wines produced. These different structural factors present in these three regions cannot be changed. Thus, the aim of this paper is to estimate the productive efficiency of the three regions of Northern Portugal and to verify if these structural factors are responsible for the different levels of efficiency.

The analysis of farms efficiency is imperative to check how the resources are being used and if its reduction can lead to the same level of production. In the farmers' vineyards context, this methodology allows to identify which ones are the most efficient and the characteristics of the system that are likely to get better performance.

This work not only contributes to the relevant literatures, as it is an original study that analysis the efficiency of grape farms in the North of Portugal, which integrates wine regions such as Minho and Trás-os-
Montes never tested, besides DRD, but also overcomes the lack of data, applying face-to-face surveys at a farm level. Furthermore, the hypothesis tested are innovative, revealing new insights into the determinants of efficiency on wine grape farms.

\section{LITERATURE REVIEW}

\subsection{Concepts and methodologies}

Efficiency is linked to a very important economy premise, the scarcity of resources. Since resources are limited, the productive efficiency analysis confirms if a Decision Making Unit (DMU) is minimizing the use of productive factors to achieve a desired amount of production. This literature began with Farrell (1957) work and since that the efficiency analysis is applied to several sectors. The efficiency analysis in agriculture sector is very common and is an ascendant topic over the years (Bravo-Ureta et al., 2007; Mareth et al., 2016; Thiam et al., 2001).

To analyse the productive efficiency, two types of methodologies have been applied in the literature, the parametric and non-parametric ones. The Stochastic Frontier Analysis (SFA) is the widely used method as a parametric and stochastic approach that was introduced by Aigner, Lovell and Schmidt (1977) and Meeusen and van Den Broeck (1977), while Data Envelopment Analysis (DEA), created by Charnes, Cooper and Rhodes (1978), is the non-parametric and deterministic method most used.

Both present advantages/potentialities and disadvantages/deficiencies that have been pointed out by several authors (Alvarez and Orea, 2001; Coelli, 1995; Cullinane et al., 2006). The DEA is an easier method to apply, because does not need to specify a functional form (Lemba et al., 2012). However, to use SFA is necessary to choose a functional form that best describe the reality, because the production function is never known in practice (Farrell, 1957). The functional forms most used in empirical studies are Cobb-Douglas and Translog. In addition, the relationship of inputs and outputs is not made in DEA, in opposite to SFA (Thiam et al., 2001). The SFA allows for measurement errors (two distinct error components) besides efficiency estimation (Cullinane, Wang, Song and Ji, 2006). The random error captures noise that is beyond of control of the producer and can affect the production such as weather, disease and pest infestation (Alem et al., 2018).

Although there is no consensus on the best methodology, Lampe and Hilgers (2015) through a bibliometric analysis verified that DEA is most used (maybe because is an easier method), but the SFA had been preferred 
in Agriculture and in Economics themes and DEA in Operation Research. Moreover, Oh and Shin (2015) state that DEA is chosen when it is not possible to express an algebraic form and to impose a distribution of inefficiency, whereas the SFA is preferable when it is possible to express a functional form and to assume distributions of efficiency and measurement errors. In addition, SFA includes random error that is very important in any agriculture activity, where there are factors beyond the farm's control (Alem et al., 2018; Moreira et al., 2011). For these reasons, we have chosen to use the SFA in this work as some previous studies have done (Coelli and Sanders, 2013; Moreira et al., 2011; Tóth and Gál, 2014).

\subsection{Literature from previous empirical studies}

Some empirical studies have analysed efficiency in wine sector and they are synthetized in Table 1.

Overall, there is a consensus in the choice of variables for output and input, with grape or wine production in quantity or value being used for output and land, labour and capital used for inputs (Aparicio et al., 2013; Brandano et al., 2019; Coelli and Sanders, 2013; Conradie et al., 2006; Freitas, 2014; Henriques et al., 2009; Marta-Costa et al.; 2017; Moreira et al., 2011; Santos et al., 2018 and 2020; Sellers-Rubio et al., 2016; SellersRubio and Más-Ruiz, 2015; Tóth and Gál, 2014; Urso et al., 2018). Intermediate consumptions also has been tested by Freitas (2014) and Santos et al. $(2018,2020)$.

The determinants of efficiency in wine sector seems to be an important analysis in previous studies and only the research papers from Aparicio et al. (2013); Coelli and Sanders (2013); Marta-Costa et al. (2017) and Sellers-Rubio et al. (2016) have not verified their impact on productive efficiency. The variables to be tested are diverse and depend on the objective of the study and whether it is been analysed grape or wine production.

As efficiency determinants intertwined to grape production we found in the literature the specialization of the farm in viticulture, training systems, irrigation, mechanization, number of plots, age of plantation, vineyard landscaping, farm slope index, climate, land ownership, farmers' age, and transformation of grapes into wine (Henriques et al., 2009; Moreira et al., 2011; Santos et al., 2020, 2018; Urso et al., 2018). Other variables are specifically connected with wine production, which is not the focus of this study.

However, some variables could be implemented in the wine sector at any stage of production in the value chain such us farm or company experience, share of paid work or average of wages paid, education or quality of human capital, public aid, financing and investment, type of grape or wine, grapes or wine with a designation of origin and market price of grapes or wine (Freitas, 2014; Henriques et al., 2009; Moreira et al., 2011; Santos et al., 2020, 2018; Sellers-Rubio and Más-Ruiz, 2015; Tóth and Gál, 2014; Urso et al., 2018).

The factors that could influence the efficiency have been discussed by several authors among the years (Mareth et al., 2017) and the effect of specific efficiency determinants is not consensual between the previous studies. The systematic literature review in efficiency analysis of Mareth et al. (2017) offers a controversial results table on the efficiency dairy farm determinants. While some of the referenced studies show a significant impact of the location, farm size, education, farm age, among others on the farm efficiency, other studies found a non-significant relationship between them.

In the wine sector, Coelli and Sanders (2013), Moreira et al. (2011), Santos et al. (2020) and Urso et al. (2018) showed that efficiency performances between regions were significantly different in Australia, Chile, Portugal and Italy, respectively. Moreover, Sellers-Rubio and MásRuiz (2015), Vidal, Pastor, Borras and Pastor (2013) and Urso et al. (2018) verified significant differences in productive efficiency levels between Designations of Origin (DO) and these DO are associated with specific regions. These findings highlight the relevance of a more detailed study of production efficiency at regional level, since all previous revised studies in the wine sector show a significant impact of the location in efficiency farm performance. However, this relationship has not always been consensual in other agricultural sectors (Mareth et al., 2017). Mostly empirical studies have shown that location has a significant influence on production efficiency (e.g. Bravo-Ureta et al., 2007; Mareth et al., 2016; and Santos et al. 2021), with some exceptions (e.g. Thiam et al., 2001; and Álvarez and González, 1999).

Size is a determinant of efficiency and productivity that has been studied for quite some time (Baumol, 1967) and can influence economic performance and competitiveness. However, this relationship can be somewhat controversial (Mareth et al., 2017; Townsend et al., 1998). In the studies conducted in the wine sector the debate remains, since some have found a positive relationship with efficiency (Brandano et al., 2019; Henriques et al., 2009; Sellers and Alampi-Sottini, 2016; Sellers-Rubio and Más-Ruiz, 2015), others a negative impact (Santos et al., 2020; Urso et al., 2018) and one a non-significative influence (Santos et al., 2018).

The positive relationship between size and productivity and efficiency can be explained by increasing returns to scale (Diewert and Fox, 2010; Sheng et al., 2015), more mechanization linked to better performance 
Table 1. Summary of previous empirical studies on efficiency analysis in wine sector.

\begin{tabular}{|c|c|}
\hline Study & Sample \\
\hline $\begin{array}{l}\text { Conradie } \\
\text { (2006) }\end{array}$ & $\begin{array}{c}70 \text { farms in Western Cape } \\
\text { Province of South Africa, } \\
\text { between } 2003 \text { and } 2004\end{array}$ \\
\hline $\begin{array}{l}\text { Henriques } \\
\text { et al. } \\
(2009)\end{array}$ & $\begin{array}{l}22 \text { farms of the Alentejo region } \\
\text { of Portugal, between } 2001 \text { and } \\
2004\end{array}$ \\
\hline $\begin{array}{l}\text { Moreira et } \\
\text { al. (2011) }\end{array}$ & $\begin{array}{c}38 \text { Chilean wine grape producers } \\
\text { that belong to Tecnovid and } 263 \\
\text { observations, in } 2005-2006\end{array}$ \\
\hline $\begin{array}{l}\text { Brandano } \\
\text { et al. } \\
(2019)\end{array}$ & $\begin{array}{l}\text { Unbalanced panel dataset of } \\
\text { conventional wineries and } \\
\text { cooperatives in the island of } \\
\text { Sardinia, Italy, between } 2004 \\
\text { and } 2009\end{array}$ \\
\hline
\end{tabular}

Aparicio et al. (2013)

24 wine Spanish DOs, in 2010

Unbalanced panel dataset of 135 Coelli and Farms (214 observations) in the Sanders Murray-Darling Basin region of (2013) Australia, between 2006-07 and 2009-10

Freitas (2014)

14 European Union countries, between 1999 and 2009

16 major wine producing

Tóth and countries, 11 of Old World and Gál (2014) 5 of New World, over the period 1995-2007

Sellers- $\quad 1257$ Spanish wineries, which Rubio and 437 are not members of any DO, Más-Ruiz and 820 are members of the 58 (2015) PDOs

Sellers-

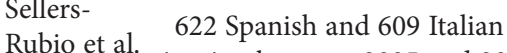
(2016) wineries, between 2005 and 2013

Marta- 95 observations in 5 Portuguese Costa et al. vineyard regions, between 1989 (2017) and 2007

$\begin{array}{ccc}\text { Methodology } & \text { Outputs } & \text { Inputs } \\ \text { SFA } & \begin{array}{c}\text { Grapes in } \\ \text { volume }\end{array} & \text { Land; labour; maquinery } \\ \text { DEA } & \begin{array}{c}\text { Grapes } \\ \text { production in } \\ \text { value }\end{array} & \begin{array}{c}\text { Agricultural area; labour; } \\ \text { machinery and equipment costs; } \\ \text { vegetal production costs; other } \\ \text { costs }\end{array} \\ \text { SFA } & \begin{array}{c}\text { Grapes } \\ \text { production per } \\ \text { block in volume }\end{array} & \begin{array}{c}\text { Size of blocks; labour cost; } \\ \text { machinery cost; other inputs } \\ \text { (e.g. fertilizer, pesticides). }\end{array}\end{array}$

Sales and

DEA earnings of wine bootstrap production in

Labour cost; capital; land value
DEA Weight Domestic sales Additive and foreign
Model
sales of wine in volume
Surface area; number of wine growers

Land; water; capital; labour;

SFA Wine grapes in other inputs costs (fertiliser, fuel volume and chemicals)

NA

Percentage of paid labour; vineyard area; wine

DEA Production in Intermediate consumption costs; value labour; capital consumption per capita; proportion of wine destined for export; degree of specialisation.

Openness to international SFA production in employment; net agricultural volume capital stock (proxy: agricultural machinery)

trade; development of financial system; quality of human capital; wine consumption (tradition of wine); old wine world

Sales volume and the profit Number of employees; funds of volume of wineries the company; level of debt

Sales revenue and profit volume of wineries

Wine and grape production in value
Number of employees; equity; level of debt

NA

Vineyard area; labour (hours); capital; total specific costs

NA
PDO; age of company; average wages paid by the company; size of company 


\begin{tabular}{|c|c|c|c|c|c|}
\hline Study & Sample & Methodology & Outputs & Inputs & Determinants \\
\hline $\begin{array}{l}\text { Urso et al. } \\
(2018)\end{array}$ & $\begin{array}{l}623 \text { Italian farms in } 2005 \text { and } \\
842 \text { farms in } 2010\end{array}$ & DEA & $\begin{array}{c}\text { Gross } \\
\text { marketable } \\
\text { output in value }\end{array}$ & Land; labour costs; capital & $\begin{array}{l}\text { Vineyard size; investments; } \\
\text { irrigation; mechanization; } \\
\text { PDO; localization; yield; } \\
\text { market price }\end{array}$ \\
\hline $\begin{array}{l}\text { Santos et } \\
\text { al. (2018) }\end{array}$ & $\begin{array}{l}20 \text { Portuguese farms in Douro } \\
\text { Region, in 2016/17 season }\end{array}$ & DEA & $\begin{array}{l}\text { Grape } \\
\text { production in } \\
\text { value }\end{array}$ & $\begin{array}{l}\text { Land, labour, capital, } \\
\text { intermediate consumption cost }\end{array}$ & $\begin{array}{c}\text { Vineyard area, farmers' age, } \\
\text { grape as main source of } \\
\text { income, training systems } \\
\text { (cordon), vineyard landscaping } \\
\text { (vertical) }\end{array}$ \\
\hline $\begin{array}{l}\text { Santos et } \\
\text { al. }(2020)\end{array}$ & $\begin{array}{l}110 \text { Portuguese farms in Douro } \\
\text { Region, in } 2017 \text { season }\end{array}$ & DEA & $\begin{array}{l}\text { Grape } \\
\text { production in } \\
\text { volume }\end{array}$ & $\begin{array}{l}\text { Land, labour, capital, } \\
\text { intermediate consumption cost }\end{array}$ & $\begin{array}{l}\text { Vineyard area, Training } \\
\text { systems, vineyard landscaping, } \\
\text { farm slope index, number of } \\
\text { farm plots, education of the } \\
\text { farmer/manager, viticulture } \\
\text { as only activity, sub-region, } \\
\text { type of wine grapes, transform } \\
\text { grapes into wine }\end{array}$ \\
\hline
\end{tabular}

(Gleyses, 2007) and higher investment capacity allowing better technological progress (Hooper et al., 2002). On the other hand, Santos et al. (2020) highlight a negative relationship between those variables due to the finer management developed and the better adaptation of the production system on a smaller area.

Another highpoint regarding the determinants of efficiency is the type of wine, which was observed by Moreira et al. (2011) and Santos et al. (2020). In both cases, grapes with superior quality have a negative and significant impact on productive efficiency. The study of Santos et al. (2020) highlights a specific type of grapes of the region with higher quality, the grapes used for Port wine, which in turn are sold at much higher prices.

Taking into account the empirical evidence of the analysed studies, in which structural (e.g. region and type of wine grapes) and non-structural (e.g. traction and farm size) determinants of efficiency are included, it becomes relevant to test for the wine grape producing systems of Northern Portugal whether structural factors determine their productive efficiency.

\section{METHODOLOGY AND DATA}

\subsection{Stochastic Frontier Analysis (SFA)}

Following the above, we assume that SFA is the better methodology to use to our purpose, since it can establish the functional form for the grapes production, includes random errors (important when production is dependent on uncontrollable factors such as climate) and it can estimate efficiency levels and examines its determinants in the same stage.
Therefore, this work follows the SFA method, through the software FRONTIER 4.1, based on Battese and Coelli (1995) and with two stages in the same step, to overcome the criticized assumption of independence of the inefficiency effects in the two-stages method (Coelli, 1996).

The stochastic frontier production function was estimated by Equation 1:

$Y_{i}=\exp \left(x_{i} \beta+v_{i}-u_{i}\right)$

Where:

$Y_{i}$ denotes the production for $i$-th farm $(i=1,2, \ldots, N)$; $x_{i}$ is a $(1 \mathrm{x} k)$ vector of values of know functions of inputs of production;

$\beta$ is a $(k \times 1)$ vector of unknown parameters to be estimated;

$v_{i}$ is assumed to be iid $N\left(0, \sigma^{2}{ }_{v}\right)$ random errors, independently distributed of the $u_{i}$;

$u_{i}$ is non-negative random variables, associated with technical inefficiency of production, which are assumed to be independently distributed, such that $u_{i}$ is obtained by truncation (at zero) of the normal distribution with mean, $z_{i} \delta$, and variance, $\sigma^{2}$;

$z_{i}$ is a $(1 \times \mathrm{m})$ vector of explanatory variables associated with technical inefficiency of production of firms over time; and

$\delta$ is an $(m \times 1)$ vector of unknown coefficients.

The technical efficiency effect, $u_{i}$, in the stochastic frontier model could be specified by Equation 2:

$u_{i}=z_{i} \delta+w_{i}$ 
Where random variable $w_{i}$ is defined by the truncation of the normal distribution with zero mean and variance, $\sigma^{2}$.

The method of maximum likelihood is proposed for simultaneous estimation of the parameters of the stochastic frontier and the model for the technical inefficiency effects. The likelihood function and its partial derivatives with respect to the parameters of the model are presented in Battese and Coelli (1993).

The technical efficiency of production for the $i$-th farm at the $t$-th observation is defined by Equation 3:

$T E_{i}=\exp \left(-u_{i}\right)=\exp \left(-z_{i} \delta+w_{i}\right)$

Following the previous literature, to specify the production frontier functions we use 2 alternative forms, the Cobb-Douglas (equation 4 such as Moreira et al. 2011) and the Translog (equation 5 such as Coelli and Sanders, 2013), which is a more flexible functional form (e.g. Rae et al., 2006 and Jin et al., 2010):

$$
\begin{aligned}
& \ln Q_{i}=\beta_{0}+\beta_{1} \ln X l_{i}+\beta_{2} \ln X t_{i}+\beta_{3} \ln X a_{i}+\beta_{4} \ln X i_{i}+ \\
& v_{i}-u_{i} \\
& \ln Q_{i}=\beta_{0}+\beta_{1} \ln X l_{i}+\beta_{2} \ln X t_{i}+\beta_{3} \ln X a_{i}+\beta_{4} \ln X i_{i} \\
& +0,5 \beta_{5}\left(\ln X l_{i}\right)^{2}+0,5 \beta_{6}\left(\ln X t_{i}\right)^{2}+0,5 \beta_{7}\left(\ln X a_{i}\right)^{2}+ \\
& 0,5 \beta_{8}\left(\ln X i_{i}\right)^{2}+\beta_{9} \ln X l_{i} \ln X t_{i}+\beta_{10} \ln X l_{i} \ln X a_{i}+\beta_{11} \\
& \ln X l_{i} \ln X i_{i}+\beta_{12} \ln X t_{i} \ln X a_{i}+\beta_{13} \ln X t_{i} \ln X i_{i}+\beta_{14} \\
& \ln X a_{i} \ln X i_{i}+v_{i}-u_{i}
\end{aligned}
$$

These variables of regressions are described in Table 2.

\subsection{Data}

The data used for this work was gathered from a sample of 154 grape producers of the North of Portugal and he agricultural season of inquiry was 2017 (crosssectional data).

The data were collected through face-to-face surveys of winegrowers and/or entrepreneurs that were generally contacted in advance by their farmers' associations or cooperative wineries. The questionnaire was appreciated by the head of this structures and also by experts from the scientific areas involved and then it was pretested. The survey data included information about the respondent and the entrepreneur, farm, vineyard, its inputs and outputs, costs and yields and information on environmental and social issues. The gathered data was then validated by a formal meeting through the World Café model realized at 2019, that was attended by around forty representatives of associations and viticulturists from the various geographical areas under study. The event was developed around two small-groups rounds of questions dedicated to (1) presentation and discussion of the results obtained; and (2) the future of viticulture. In the first panel the aim was to explore and justify the findings and, in the second panel, to identify the main variables of the system that the sector's agents consider relevant for its analysis and evolution.

The variables used for output, input and as explanatory variables of efficiency were chosen according with (1) the characteristics of the activity in the North of Portugal, which were collected by the surveys and (2) the variables used in previous empirical studies (Brandano et al., 2019; Coelli and Sanders, 2013; Fuensantana et al., 2015; Marta-costa et al., 2017; Moreira et al., 2011; Santos et al., 2018; Sellers-Rubio et al., 2016; Sellers-Rubio and Más-Ruiz, 2015; Urso et al., 2018). Both procedures conduct to the output and inputs variables that are described in Table 2 .

The explanatory variables of efficiency translate not only the characteristics of region profiles from the North of Portugal and the chosen variables in the previous studies, but also the availability of data. As output (grapes production) and input (land, labour, capital and intermediate consumption costs) variables we used the most consensual determinants found in the previous studies. As explanatory variables we included the size of the vineyard, which is a determinant of preference in the agriculture sector (Freitas, 2014; Henriques et al., 2009; Santos et al., 2020, 2018; Sellers-Rubio and Más-Ruiz, 2015; Urso et al., 2018); the number of plots that revealed a significant effect on grapes production efficiency of Douro in the study of Santos et al. (2020); and the mechanization, reflected by the number of hours of traction, was considered forasmuch as an unusual behaviour in this variable due to the different landscape physiography of the region.

The geographical location and type of wine produced were also tested as determinants in the efficiency approach by virtue of the structural context of the region of study. In this matter, Moreira et al. (2011) show that red and premium grapes affect efficiency negatively which makes more relevant the inclusion of Port and Alvarinho wines production as explanatory variables, due to the quality of this type of wine with the correspondingly highest remuneration on the market. In our sample, the Port grapes are the most expensive $(1,21 €$ versus $0,41 €$ in the regular grapes). All these variables and their descriptive statistics are shown in Table 2.

The analysis of Table 2 shows a large discrepancy of the variables from the grape farms contacted, but supported in a large distinct sample of farms. 
Table 2. Descriptive Statistics of Inputs and Outputs used from the database collected.

\begin{tabular}{|c|c|c|c|c|c|}
\hline \multicolumn{2}{|c|}{ Type of Variables } & \multirow{2}{*}{$\begin{array}{l}\text { Average } \\
81079.48\end{array}$} & \multirow{2}{*}{$\begin{array}{c}\text { Standard-deviation } \\
134245.31\end{array}$} & \multirow{2}{*}{$\begin{array}{c}\text { Min. } \\
3300.00\end{array}$} & \multirow{2}{*}{$\frac{\text { Max. }}{900000.00}$} \\
\hline Output & Production $(\mathrm{kg})-\mathrm{Q}$ & & & & \\
\hline Input & Land (ha) - Xl & 14.00 & 25.94 & 1.00 & 184.38 \\
\hline & Labour (days) - Xt & 768.91 & 1725.27 & 42.33 & 12602.64 \\
\hline & Capital (Amortization $€)-X a$ & 6784.86 & 9627.89 & 0.00 & 72701.03 \\
\hline & Intermediate Consumption $(€)-X i$ & 21009.67 & 40716.13 & 634.38 & 449861.15 \\
\hline \multirow[t]{5}{*}{ Explanatory } & Vineyard size (index) & 100.00 & 185.28 & 7.14 & 1316.99 \\
\hline & Plots (number) & 5.82 & 5.97 & 1.00 & 51.00 \\
\hline & Port wine (\%) & 30.59 & 26.87 & 0 & 1 \\
\hline & Alvarinho (\%) & 6.34 & 23.47 & 0 & 1 \\
\hline & Traction (hours/ha) & 32.85 & 14.22 & 0 & 74.48 \\
\hline
\end{tabular}

\section{RESULTS AND DISCUSSION}

Table 3 contains the results of efficiency estimation using Equation 3 for Cobb-Douglas and Translog functional forms. In general, we could see that the average efficiency and efficiency scores trends in Table 3 are almost identical in both specifications. The average efficiency for the farms that produce grapes are around 68 and $67 \%$ and its efficiency levels are very discrepant between the production units. Relatively to the regions, Minho appears to be the most efficient region (0.9859 and 0.9898), while the most inefficient is Trás-os-Montes region (0.4776 and 0.4877).

The size class of the farms has also proved relevant in the achieved efficiency levels, but in a conversely way. The farms that have more than 20 ha have the lower average efficiency scores (0.5915 and 0.4470) and the smallest ones have highest average efficiency scores (around 0.72).

The classes of plots, which coincide with its quartiles, show an increase of its efficiency scores with the number of plots, but it is in the class with the highest number of plots (above 6) the efficiency values decreased. The data collected by the surveys exposes that when the size of the farms increases, the number of plots also increases, however this variable appears to have distinct influences on efficiency scores (Table 3). The situation can be explained in two ways. On the one hand, less plots may lead to a lower use of production factors (lower costs), such as traction, which will conduct to greater efficiency. On the other hand, a larger number of plots may allow a better adaptation of the system used in each plot to its conditions and consents to higher efficiency level. This situation was also reported in the recent study of Santos et al. (2020).

Relatively to the traction, we observe a general positive relationship between this production factor and the average of efficiency of farms.
Table 4 reports the results of SFA gathered with Equation 4 and 5, that uses a Coob-Douglas and a Translog functional forms and regress the inputs and determinants of inefficiency in the same stage. Observing the LR test-statistic (2) we cannot reject the null hypothesis of using Cobb-Douglas versus Translog. As an alternative, we present the results of both, since the Translog is considered a less restrictive form. Moreover, the results presented by this second alternative are very similar, reinforcing robustness and adding information that may be of interest to the discussion. Observing the LR test-statistic (1), the determinants of inefficiency present a clear overall significance in the both models. However, when Translog is used, there are more factors that are significant (size, plots, Douro and traction).

All coefficients of productive factors are positive and they demonstrate a direct relationship with production. All inputs variables are significative, except capital in the Cobb-Douglas specification and labour in the Translog functional form. According to the partial elasticity of production, the most influential variable are land in the two models (0.6553 and 0.597). All significative inputs variables are significative at $1 \%$, with exception of labour in the Cobb-Douglas that are significative at $10 \%$.

The results of both specifications show that Trás-osMontes region and Port wine grapes influence negatively and significantly (at 5\% and 1\% respectively) the farms efficiency performance. In addition, the Translog model, show that the number of plots influence the efficiency levels positively and significantly (at $1 \%$ ), while the vineyard size, Douro region and the traction affect it negatively and also significantly (at 10\%, 5\% and 5\% respectively).

Firstly, the farms that produce more percentage of grapes intended for Port wine are more inefficient. This is in agreement with Santos et al. (2020). In addition, Moreira et al. (2011) also verifies that some type of wine grapes (red and premium) influences the farms efficiency 
Table 3. Average efficiency scores.

\begin{tabular}{|c|c|c|c|c|}
\hline Variables & & $\begin{array}{l}\text { Observa- } \\
\text { tions }\end{array}$ & $\begin{array}{l}\text { Average } \\
\text { efficiency } \\
\text { - Cobb- } \\
\text { Douglas }\end{array}$ & $\begin{array}{c}\text { Average } \\
\text { efficiency - } \\
\text { Translog }\end{array}$ \\
\hline North & & 154 & 0.6814 & 0.6706 \\
\hline \multirow[t]{3}{*}{ Region } & Douro & 110 & 0.6058 & 0.5885 \\
\hline & Minho & 34 & 0.9859 & 0.9898 \\
\hline & TOM & 10 & 0.4776 & 0.4877 \\
\hline \multirow[t]{4}{*}{ Farm dimension (ha) } & {$[1 ; 5[$} & 51 & 0.7129 & 0.7254 \\
\hline & {$[5 ; 10[$} & 47 & 0.7161 & 0.7221 \\
\hline & {$[10 ; 20[$} & 37 & 0.6400 & 0.6253 \\
\hline & $\geq 20$ & 19 & 0.5915 & 0.4843 \\
\hline \multirow[t]{4}{*}{ Plots (number) } & {$[0 ; 3[$} & 35 & 0.6477 & 0.6484 \\
\hline & {$[3 ; 4[$} & 24 & 0.6909 & 0.6925 \\
\hline & {$[4 ; 7[$} & 54 & 0.7196 & 0.7204 \\
\hline & $\geq 7$ & 41 & 0.6542 & 0.6110 \\
\hline \multirow[t]{3}{*}{ Type of wine (\%) } & Port & 108 & 0.5997 & 0.5817 \\
\hline & Alvarinho & 12 & 0.9876 & 0.9915 \\
\hline & Others & 34 & 0.8328 & 0.8397 \\
\hline \multirow[t]{4}{*}{ Traction (hours) } & {$[0 ; 23,06[$} & 38 & 0.6320 & 0.6189 \\
\hline & {$[23.06 ; 29.92[$} & 39 & 0.6427 & 0.6092 \\
\hline & {$[29,92 ; 42,52[$} & 39 & 0.6991 & 0.6951 \\
\hline & $\geq 42,52$ & 38 & 0.7523 & 0.7600 \\
\hline
\end{tabular}

Note: Plots and Traction intervals are based on quartiles.

scores. The lower yields of this grapes of higher quality and the severe and protective regulation, which imposes limits to the production of the Port wine, can be the reason for its lower levels of efficiency. However, the situation is compensated by the higher prices pay per $\mathrm{kg}$ of grapes for this type of wine (1.21€) compared to the regular grapes $(0.41 €)$.

Secondly, Trás-os-Montes reveals to be the most inefficient region and this is aligned with the low relevance of this wine region of Portugal, with less land productivity from the North $(3698$ and $6559 \mathrm{~kg} / \mathrm{ha}$, respectively, from our database) and yet with the fewer recognized wines.

Additionally, the Translog functional form presents others results that could complement the analysis.

This model detects a negative impact of farm size and the explanation of negative influence of the farm size is supported in the results of Table 3, which present a decrease in average efficiency when the farm size increases. As a matter of fact, the farms with less than 10 hectares have higher yields with more than $6754 \mathrm{~kg}$ of grapes produced per hectare, while the biggest farms ( $\geq 20$ ha) have the lowest productivity ( 5715 $\mathrm{kg} / \mathrm{ha}$ ). In addition, the small farms benefit from a larger share of family labour and the biggest farms of our database present the highest average real costs per hectare ( $3545 € /$ ha against 3371 of the total average). This inverse relationship between size and efficiency is supported in some previous studies (e.g. Akamin, Bidogeza, Minkoua and Afari-Sefa, 2017; Chen, Huffman and Rozelle, 2011; Urso et al., 2018). Recently in the viticulture sector, Santos et al. (2020) also confirmed an opposite connection of the same variables, in the Portuguese Douro region.

The findings with the number of plots in Trans$\log$ specification are also consistent with Table 3 and corroborate the affirmation of the management of the production system can be more specific to the characteristics of land and the type of grapes when land are divided in plots. Also the work of Moreira et al. (2011) support this evidence which conduct to a more efficient production system.

Although the size of the farm and the plots have a direct and positive relationship between them, they have an opposite influence on efficiency as already predicted by the results of Table 3 .

Besides Trás-os-Montes, Douro demonstrates to be less efficient than Minho (in the Translog specification) and several indicators can support this result. Douro has lower productivity (5784 kg/ha against 9909 in Minho) and it is more labour-intensive (53 days/ha against 48 in Minho) due to the mountain viticulture that characterizes the region which exacerbates the difficulties of mechanisation and, in turn, increases the production costs. This is also confirmed in the Hogg and Rebelo (2018) study, which refer Douro as very dependent on labour, a scarce production factor in the region and in the sector.

The importance of the region in efficiency scores has been demonstrated in many previous studies such as Bravo-Ureta et al., (2007); Coelli and Sanders (2013); Mareth et al., (2016); Moreira et al. (2011); Santos et al., (2020); Sellers-Rubio and Más-Ruiz (2015); Thiam et al., (2001); Urso et al. (2018) and Vidal et al. (2013).

Yet, the grapes used for Port wine are produced only in the Douro region and they show a negative relationship with efficiency levels. However, the prices charged for these types of grapes can compensate its production and originate a positive impact on profitability, as mentioned before. Relatively to the Alvarinho type of wine, it was not proved any significant influence on farms productive efficiency.

The traction per hectare, when used more intensively, leads to higher farm costs and a negative relationship with production efficiency. This result make sense and it is in accordance with Urso et al. (2018), but the authors measured the use of the production factor in horsepower. However, the mechanization is important to make 
Table 4. Results of SFA.

\begin{tabular}{|c|c|c|}
\hline $\begin{array}{l}\text { Variables } \\
\text { Frontier Production } \\
\text { Function }\end{array}$ & $\begin{array}{l}\text { Cobb-Douglas } \\
\text { specification } \\
\text { Coefficient }\end{array}$ & $\begin{array}{c}\text { Translog specification } \\
\text { Coefficient }\end{array}$ \\
\hline Constant & $0.4385^{\star * *}(0,0697)$ & $0.4091^{* * *}(0.0616)$ \\
\hline $\ln X l$ & $0.6553^{\star * *}(0,1244)$ & $0.5971^{\star * \star}(0.1169)$ \\
\hline $\ln X t$ & $0.1883^{\star}(0,1020)$ & $0.1588(0.0987)$ \\
\hline $\ln X a$ & $0.0282(0,0358)$ & $0.1612^{\star * *}(0.0543)$ \\
\hline $\ln X i$ & $0.1826^{* * *}(0,0639)$ & $0.1983^{\star * *}(0.0747)$ \\
\hline $0,5(\ln X l)^{2}$ & & $-0.3580(0.5061)$ \\
\hline $0,5(\ln X t)^{2}$ & & $-0.0852(0.4319)$ \\
\hline $0,5(\ln X a)^{2}$ & & $0.0195(0.0331)$ \\
\hline $0,5(\ln X i)^{2}$ & & $-0.0653(0.1234)$ \\
\hline $\ln X l \ln X t$ & & $0.1674(0.4218)$ \\
\hline $\ln X l \ln X a$ & & $0.1712(0.1534)$ \\
\hline $\ln X l \ln X a$ & & $-0.0575(0.2179)$ \\
\hline $\ln X t \ln X a$ & & $-0.0622(0.1480)$ \\
\hline $\ln X t \ln X i$ & & $0.1114(0.1478)$ \\
\hline $\ln X a \ln X i$ & & $-0.0076(0.0807)$ \\
\hline Constant & $-0.7636(0,6073)$ & $-0.5952^{\star * *}(0.2050)$ \\
\hline Size & $0.0003(0,0003)$ & $0.0011^{\star}(0.0006)$ \\
\hline Plots & $-0.0068(0,0048)$ & $-0.0105^{* * *}(0.0039)$ \\
\hline Douro & $0.6647(0,5105)$ & $0.4690^{* *}(0.2314)$ \\
\hline Trás-os-Montes & $1.4488^{\star *}(0,5871)$ & $1.2538^{\star * \star}(0.2726)$ \\
\hline Port & $1.3672^{* * *}(0,1907)$ & $1.3836^{* * *}(0.2264)$ \\
\hline Alvarinho & $-0.1551(0,6162)$ & $-0.0989(0.0988)$ \\
\hline Traction & $0.0021(0,0020)$ & $0.0017^{* *}(0.0008)$ \\
\hline Sigma-squared & $0.1351^{* * *}(0,0147)$ & $0.1208^{\star * \star}(0.0121)$ \\
\hline Gamma & $0.0846^{* * *}(0,0171)$ & $0.0518^{* *}(0.0265)$ \\
\hline LR test-statistic (1) & $94.19^{* * *}$ & $99.14^{* * *}$ \\
\hline LR test-statistic (2) & 15.54 & \\
\hline
\end{tabular}

$*, * *, * *$ Significance at $10 \%, 5 \%$ and $1 \%$, respectively. Standard error in parentheses.

(1) This test-statistic allows us to test the hypothesis of the absence of inefficiency effects.

(2) This test-statistic allows us to test the Cobb-Douglas versus Translog specification.

the production process faster and can solve the labour shortage in the region and others studies proved their importance (Abass et al., 2017; Hormozi et al., 2012; Park et al., 2018).

In this sense, the hypothesis that structural factors are responsible for different efficiency levels should be accepted, since the intrinsic characteristics of the region and the type of wine specifically produced in a location affect farm efficiency. In addition, the farm size and number of plots can be difficult to change as it can be associated with structural characteristics of the region such as slope, topography of the land and social characteristics. Furthermore, efficient mechanization can be difficult when it comes to a region like Douro where mountain viticulture with steep slopes prevails.

\section{CONCLUSION}

Productive efficiency analysis is crucial to verify whether the wine-growing farms are using the available resources efficiently to produce grapes and to identify which characteristics make the farms less efficient.

To analyse efficiency in the wine grapes farms of the Northern of Portugal, SFA was used, because it allows to separate the efficiency from other factors through random errors, which is essential for agriculture that has many external factors affecting its production and efficiency. In addition, the use of two specifications (CobbDouglas and Translog) allowed for more robustness of the results since both model findings are similar and complement each other.

This study estimates an average efficiency score in North of Portugal around $0.68 / 0.67$, leading to the conclusion that farms can improve their efficiency by $32 / 33 \%$. The most significant determinants in both models were Trás-os-Montes region and the production of Port wine grapes, which were shown to have a negative influence on farm efficiency. In addition, the Translog specification also shows that the number of plots and Minho region positively affect farm efficiency, while the size of vineyards, Douro region and traction have a negative impact.

We can conclude that most variables that affect efficiency are structural and therefore cannot be changed (e.g. region and specific type of wine grapes produced), whilst other determinants are difficult to modify (e.g. farm size or number of plots). Hence the producer cannot do much to improve farm efficiency in this perspective. We believe that these structural factors or intrinsic characteristics explain the main differences in efficiency between regions such as edapho-climatic conditions and the type of wine produced exclusively in one region (Alvarinho and Port Wine).

However, this study makes reference to some performance determinants that are likely to change, such as farm size, number of plots and traction hours. In this sense, the policies that support parcelling can be questioned, since the small farms (predominant in the region) and the ones with a larger number of plots are the most efficient. Relatively to the use of traction, despite its inefficient use, this practice is important for those regions where labour is increasingly scarce, notwithstanding its difficulty in mountain viticulture region like Douro. 
Minho as undoubtedly the most efficient region (0.99) against Trás-os-Montes (0.48 and 0.49) and Douro (0.61 and 0.59). Therefore, despite its intrinsic characteristics, Minho seems to use its production factors more efficiently and the region can be used as a model for the others geographical areas to adopt better production routines or new technologies.

In conclusion, the farms will be more efficient if its management fits the specific structural factors (climate, soil type, slope of the land, type of grapes, economy, market, crop size, complexity of the production process that are mostly specific to the region, the farm, or even the plot). However, each farm is unique and has a set of inimitable resources that makes them more heterogeneous. Thus, it is expected that farms operating in different contexts, with distinct technologies, resources and using diverse combinations of them will have dissimilar levels of efficiency.

Although this paper studies the efficiency of the viticulture sector, the profitability of the farm has been the most important management issue. Small farms can be more efficient due to more precise practices, where their managers or farmers control and identifies its needs more easily. However, since big farms transform $83 \%$ of their grapes into wine $(11 \%$ of the sample with an average of $65 \mathrm{ha})$, they can earn more at the end of the value chain. Grapes production for Port wine may be inefficient, but the price paid per kilogram of grapes (1.21€ against $0.41 €$ for still wine in Douro) makes them more profitable. Taking these conclusions into consideration, an analysis of the grape farms profitability and efficiency-related would be important for future research together with its contribution to the sustainability of production systems.

\section{ACKNOWLEDGEMENTS}

This work was supported by the R\&D Project INNOVINE \& WINE - Vineyard and Wine Innovation Platform - Operation NORTE -01-0145-FEDER-000038, co-funded by the European and Structural Investment Funds (FEDER) and by Norte 2020 (Programa Operacional Regional do Norte 2014/2020).

\section{REFERENCES}

Abass, A., Amaza, P., Bachwenkizi, B., Wanda, K., Agona, A., Cromme, N., 2017. The impact of mechanized processing of cassava on farmers' production efficiency in Uganda. Appl. Econ. Lett. 24, 102-106. https://doi.org/10.1080/13504851.2016.1167817
Aigner, D., Lovell, C.A.K., Schmidt, P., 1977. Formulation and estimation of stochastic frontier production function models. J. Econom. 6, 21-37.

Akamin, A., Bidogeza, J.-C., Minkoua N, J.R., Afari-Sefa, V., 2017. Efficiency and productivity analysis of vegetable farming within root and tuber-based systems in the humid tropics of Cameroon. J. Integr. Agric. 16, 1865-1873. https://doi.org/10.1016/S20953119(17)61662-9

Alem, H., Lien, G., Hardaker, J.B., 2018. Economic performance and efficiency determinants of crop-producing farms in Norway. Int. J. Product. Perform. Manag. 67, 1418-1434. https://doi.org/10.1108/ IJPPM-01-2018-0026

Álvarez, A. M., González, E., 1999. Using Cross-Section Data to Adjust Technical Efficiency Indexes Estimated With Panel Data. Am. J. Agric. Econ.. 81, 894-901. https://doi.org/10.2307/1244332

Alvarez, A., Orea, L., 2001. Different approaches to model multi-species fisheries using a primal approach. Effic. Ser. Pap. 3, 1.

Baumol, W. J., 1967. Macroeconomics of unbalanced growth: the anatomy of urban crisis. Am. Econ. Rev., 57, 415-426.

Brandano, M.G., Detotto, C., Vannini, M., 2019. Comparative Efficiency Of Agricultural Cooperatives And Conventional Firms In A Sample Of Quasi-Twin Companies. Ann. Public Coop. Econ. 90, 53-76.

Bravo-Ureta, B.E., Solís, D., Moreira López, V.H., Maripani, J.F., Thiam, A., Rivas, T., 2007. Technical efficiency in farming: A meta-regression analysis. J. Product. Anal. 27, 57-72. https://doi.org/10.1007/s11123-0060025-3

Charnes, A., Cooper, W.W., Rhodes, E., 1978. Measuring the efficiency of decision making units. Eur. J. Oper. Res. https://doi.org/10.1016/03772217(78)90138-8

Chen, Z., Huffman, W.E., Rozelle, S., 2011. Inverse relationship between productivity and farm size: The case of China. Contemp. Econ. Policy 29, 580-592. https://doi.org/10.1111/j.1465-7287.2010.00236.x

Coelli, T.J., 1995. Recent developments in frontier modelling and efficiency measurement. Aust. J. Agric. Resour. Econ. 39, 219-245.

Coelli, T.J., 1996. A guide to FRONTIER version 4.1: a computer program for stochastic frontier production and cost function estimation. CEPA Working papers.

Coelli, T.J., Sanders, O., 2013. The technical efficiency of wine grape growers in the Murray-Darling Basin in Australia, in: Wine Economics. Springer, pp. 231249. 
Conradie, B., Cookson, G., Thirtle, C., 2006. Efficiency and farm size in Western Cape grape production: Pooling small datasets. South African J. Econ. 74, 334-343.

Cullinane, K., Wang, T.F., Song, D.W., Ji, P., 2006. The technical efficiency of container ports: Comparing data envelopment analysis and stochastic frontier analysis. Transp. Res. Part A Policy Pract. 40, 354374. https://doi.org/10.1016/j.tra.2005.07.003

Diewert, W., Fox, K., 2010. Malmquist and törnqvist productivity indexes:returns to scale and technical progress with imperfect competition. J. Econ., 101, 73-95. https://doi.org/10.1007/s00712-010-0137-0

Farrell, M.J., 1957. The measurement of productive efficiency. J. R. Stat. Soc. Ser. A 120, 253-290.

Fleming, E., Mounter, S., Grant, B., Griffith, G., Villano, R., 2014. The New World challenge: Performance trends in wine production in major wine-exporting countries in the 2000s and their implications for the Australian wine industry. Wine Econ. Policy 3, 115-126. https://doi.org/10.1016/j.wep.2014.12.002

Freitas, R., 2014. Sobre a eficiência dos países produtores de uvas para vinho na União Europeia : uma aproximação DEA em duas etapas. Master thesis in Universidade Católica Portuguesa.

Fuensantana, M.J.R., Sancho, F.H., Marco, V.S., 2015. In vino veritas : competitive factors in wine-producing industrial districts. J. Reg. Res. 32, 149-164.

Gleyses, G., 2007. Rendement d'échelle et économies d'échelle en agriculture. In: T.editor (Ed.), Cemagref, Action 4, UMR G-Eau, Montpellier, p. 29, politiquespubliques, aversion au risque des agriculteurs et demande en eau d'irrigation.

Goncharuk, A.G., Figurek, A., 2017. Efficiency of winemaking in developing countries. Int. J. Wine Bus. Res. 29, 98-118. https://doi.org/10.1108/IJWBR-02-2016-0007

Henriques, P.D. de S., Carvalho, M.L. da S., Fragoso, R.M. de S., 2009. Technical efficiency of portuguese wine farms. New Medit 8, 4-9.

Hogg, T., Rebelo, J. (2018), Rumo estratégico para o setor dos vinhos do Douro e Porto. ISBN: 978-989-704344-4, Vila Real: UTAD.

Hooper, S., Martin, P., Love, G., Fisher, B. S., 2002. Farm size and productivity: where are the trends taking us?. Aust Commod, 9, 495.

Hormozi, M.A., Asoodar, M.A., Abdeshahi, A., 2012. Impact of Mechanization on Technical Efficiency: A Case Study of Rice Farmers in Iran. Procedia Econ. Financ. https://doi.org/10.1016/s22125671(12)00021-4

IVV (2019). Dados Estatísticos do setor vitivinícola. Instituto da Vinha e do Vinho.
Lampe, H.W., Hilgers, D., 2015. Trajectories of efficiency measurement: A bibliometric analysis of DEA and SFA. Eur. J. Oper. Res. 240, 1-21. https://doi. org/10.1016/j.ejor.2014.04.041

Lemba, J., D’Haese, M., D'Haese, L., Frija, A., Speelman, S., 2012. Comparing the technical efficiency of farms benefiting from different agricultural interventions in Kenya's drylands. Dev. South. Afr. 29, 287-301. https://doi.org/10.1080/0376835X.2012.675698

Mareth, T., Thomé, A. M. T., Scavarda, L. F., Oliveira, F. L. C., 2017. Technical efficiency in dairy farms: research framework, literature classification and research agenda. Int. J. Product. Perform. Manag., 66, 380-404.

Mareth, T., Thomé, A.M.T., Cyrino Oliveira, F.L., Scavarda, L.F., 2016. Systematic review and meta-regression analysis of technical efficiency in dairy farms. Int. J. Product. Perform. Manag. 65, 279-301. https://doi.org/10.1108/IJPPM-02-2015-0027

Marta-costa, A., Martinho, V., Santos, M., 2017. Productive Efficiency of Portuguese vineyard regions. Reg. Sci. Inq. IX, 97-107.

Meeusen, W., van Den Broeck, J., 1977. Efficiency estimation from Cobb-Douglas production functions with composed error. Int. Econ. Rev. (Philadelphia). 435-444.

Moreira, V.H., Troncoso, J.L., Bravo-Ureta, B.E., 2011. Technical efficiency for a sample of Chilean wine grape producers: A stochastic production frontier analysis. Cienc. e Investig. Agrar. 38, 321-329. https://doi.org/10.4067/S0718-16202011000300001

Oh, S.-C., Shin, J., 2015. The impact of mismeasurement in performance benchmarking: A Monte Carlo comparison of SFA and DEA with different multiperiod budgeting strategies. Eur. J. Oper. Res. 240, 518-527. https://doi.org/10.1016/j.ejor.2014.07.026

OIV (2019). 2019 Statistical Report on World Viticulture. International Organization of Vine and Wine.

Park, A.G., McDonald, A.J., Devkota, M., Davis, A.S., 2018. Increasing yield stability and input efficiencies with cost-effective mechanization in Nepal. F. Crop. Res. https://doi.org/10.1016/j.fcr.2018.08.012

Santos, M., Marta-Costa, A., Santos, C., Galindro, A., 2018. Efficiency of wine grape growers at farm level: a case study. E3S Web Conf. 50, 01010. https:// doi.org/10.1051/e3sconf/20185001010

Santos, M., Rodríguez, X.A., Marta-Costa, A., 2020. Efficiency analysis of viticulture systems in the Portuguese Douro region. Int. J. Wine Bus. Res. https:// doi.org/10.1108/IJWBR-10-2019-0052

Santos, M.; Marta-Costa, A.; Rodríguez, X. A., 2021. Meta-regression analysis of technical (in)efficien- 
cy in agriculture: a regional approuch. Econ. Reg. forthcoming.

Sellers-Rubio, R., Alampi Sottini, V., Menghini, S., 2016. Productivity growth in the winery sector: evidence from Italy and Spain. Int. J. Wine Bus. Res. 28, 59-75. https://doi.org/10.1108/IJWBR-05-2015-0019

Sellers-Rubio, R., Más-Ruiz, F.J., 2015. Economic efficiency of members of protected designations of origin: sharing reputation indicators in the experience goods of wine and cheese. Rev. Manag. Sci. 9, 175196. https://doi.org/10.1007/s11846-014-0124-x

Sheng, Y., Zhao, S., Nossal, K., Zhang, D., 2015. Productivity and farm size in Australian agriculture: reinvestigating the returns to scale. Aust. J. Agric.Resour. Econ. 59, 16-38. https://doi. org/10.1111/1467-8489.12063

Thiam, A., Bravo-Ureta, B.E., Rivas, T.E., 2001. Technical Efficiency in developing country agriculture: a meta-analysis. Agric. Econ. 25, 235-243.

Tóth, J., Gál, P., 2014. Is the New Wine World more efficient? Factors influencing technical efficiency of wine production. Stud. Agric. Econ. 116, 95-99. https://doi.org/10.7896/j.1411

Townsend, R. F., Kirsten, J., Vink, N., 1998. Farm size, productivity and returns to scale in agriculture revisited: a case study of wine producers in South Africa. Agric. Econ., 19, 175-180. https://doi. org/10.1111/j.1574-0862.1998.tb00524.x

Urso, A., Timpanaro, G., Caracciolo, F., Cembalo, L., 2018. Efficiency analysis of Italian wine producers. Wine Econ. Policy 7, 3-12. https://doi.org/10.1016/j. wep.2017.11.003

Vidal, F., Pastor, J.T., Borras, F., Pastor, D., 2013. Efficiency analysis of the designations of origin in the Spanish wine sector. Spanish J. Agric. Res. 11, 294304. https://doi.org/10.5424/sjar/2013112-3607 